\title{
KEBIJAKAN PROGRAM PENDIDIKAN BERBASIS KEUNGGULAN LOKAL DI SEKOLAH MENENGAH ATAS NEGERI 2 PEKALONGAN
}

\section{THE POLICY OF EDUCATIONAL PROGRAM BASED ON LOCAL CONTENT IN STATE SENIOR HIGH SCHOOL 2 PEKALONGAN}

\author{
Subijanto \\ Pusat Penelitian Kebijakan Pendidikan dan Kebudayaan \\ Gedung E lantai 19, Jalan Jenderal Sudirman Senayan, Jakarta Pusat \\ e-mail: subijanto2012@gmail.com
}

Naskah diterima tanggal: 09/02/2015, Direvisi akhir: 09/07/2015, Disetujui tanggal: 01/08/2015

\begin{abstract}
This study aims to analyze: 1) the sustainability of the educational program and its use of local content in public senior secondary school 2 Pekalongan; 2) the advantages of the program for students; and 3) the advantages of the program for the surrounding societies. This case study used a descriptive method. The results showed that, 1) the educational program, which is based on local content, will continue to run despite the Directorate for Development of Senior Secondary School's decision to stop funding it, and despite tidal floods, which created difficulty in environmental conditions; 2) the advantages of the program for students are, a) to know the local culture of their region; $b$ ) to understand several aspects related to the local culture of their region; c) to be able to manage resources of the local environment; and d) to be able to make a living in this context while preserving culture, tradition and the resources of the area; 3) the advantages of the program for the societies around the school have not yet included a significant increase in economic value (additional income/welfare). It can be concluded that the educational program, which is based on local content, in Public Senior Secondary School 2 in Pekalongan was not yet fully successful. However, this program will continue to run despite adverse environmental conditions due to tidal flood.
\end{abstract}

Keywords: educational policy, educational program based on local content, senior secondary school, maritime/fishery

\begin{abstract}
Abstrak: Tujuan studi ini untuk menganalisis: 1) keberlanjutan kebijakan program pendidikan berbasis keunggulan lokal di Sekolah Menegah Atas Negeri 2 Pekalongan; 2) manfaat program pendidikan berbasis keunggulan lokal bagi peserta didik; dan 3) manfaat terhadap nilai tambah ekonomi bagi masyarakat di sekitar sekolah. Studi kasus ini menggunakan metode deskriptif. Hasil studi menunjukkan bahwa: 1) kebijakan program pendidikan berbasis keunggulan lokal tetap dilanjutkan meskipun pihak Direktorat Pembinaan Sekolah Menengah tidak lagi memberikan bantuan dana sharing dan kondisi lingkungan kurang kondusif karena sering terjadi bencana tahunan air rob; 2) manfaat pendidikan berbasis keunggulan lokal bagi peserta didik antara lain, a) mengetahui keunggulan lokal di daerahnya, b) memahami berbagai aspek yang berhubungan dengan keunggulan lokal di daerahnya; c) mampu mengolah sumber daya yang berkaitan dengan keunggulan lokal; dan d) dapat menghidupi dirinya manakala memperoleh penghasilan, sekaligus melestarikan budaya, tradisi, dan sumber daya yang menjadi unggulan daerah; 3) manfaat pendidikan berbasis keunggulan lokal bagi masyarakat sekitar belum memberikan nilai tambah (ekonomi) bagi masyarakat di sekitar sekolah. Studi ini menyimpulkan bahwa kebijakan pendidikan berbasis keunggulan lokal di Sekolah Menengah Atas Negeri 2 Pekalongan belum berhasil sebagaimana mestinya, tetapi tetap dilanjutkan walaupun kondisi lingkungan mengalami bencana banjir air rob setiap tahunnya.
\end{abstract}

Kata kunci: kebijakan pendidikan, pendidikan berbasis keunggulan lokal, sekolah menengah atas, perikanan 


\section{PENDAHULUAN}

Pada tahun 2000 Departemen Pendidikan Nasional menetapkan kebijakan program pendidikan yang berorientasi pada kecakapan hidup (life skill) dengan pendekatan pendidikan berbasis luas (broad based education) yang diberlakukan bagi semua jenis, jenjang, dan satuan pendidikan formal maupun nonformal yang kemudian diimplementasikan pada tahun 2002 (Direktorat Pembinaan Sekolah Menengah Atas, 2010). Secara teoretik, perubahan tersebut bukan sebagai suatu kebijakan yang dilandasi oleh pragmatisme sesaat namun, merupakan upaya penemuan kembali jati diri sekolah (re-inventing school) yang seharusnya dilakukan pada setiap satuan dan jenis pendidikan.

Dalam implementasi program kecakapan hidup, Direktorat Pembinaan Sekolah Menengah Atas (SMA) melalui Bagian Proyek Broad Based Education (BBE) Life Skill selama tiga tahun (2002-2004) menangani langsung bantuan operasional (pembinaan dan dana sharing). Pada tahun 2005, pemerintah mendorong agar sekolah berupaya mampu mencapai 8 (delapan) Standar Nasional Pendidikan (SNP). Dalam kurun waktu dua tahun kemudian, Kementerian Pendidikan Nasional (Kemdiknas) mempercepat ketercapaian profil rintisan sekolah kegiatan mandiri (RSKM), Pembelajaran Berbasis Keunggulan Lokal (PBKL), dan Rintisan Pusat Sumber Belajar (RPSB), dengan menunjuk 441 SMA sebagai sekolah rintisan RSKM dan 100 SMA sebagai sekolah rintisan pelaksana PBKL (Direktorat Pembinaan Sekolah Menengah Atas, 2010).

Tahun 200833 SMA ditunjuk sebagai RPSB. Kemudian mulai tahun 2008 Kemdiknas mewujudkan bentuk rintisan sekolah kegiatan mandiri (SKM), PBKL, dan Pusat Sumber Belajar (PSB) yang berlangsung secara singkat sampai akhir tahun 2009. Pada akhirnya, pada tahun 2013 Kemdiknas mengalihkan perhatiannya terhadap SMA Model SKM, PBKL, dan PSB sebagai sekolah dalam kategori mandiri, di mana SMA tersebut dianggap telah memenuhi kedelapan standar dan/atau hampir memenuhi delapan Standar Nasional Pendidikan (SNP).

Penyelenggaraan pendidikan pada setiap satuan pendidikan yang bermutu, harus mengacu pada SNP sebagaimana diamanatkan dalam Peraturan Pemerintah Republik Indonesia Nomor 19 Tahun 2005 yang telah diubah menjadi Peraturan Pemerintah Republik Indonesia Nomor 32 tahun 2013 di mana setiap penyelenggara pendidikan harus mampu mencapai delapan SNP, yaitu 1) standar Isi, 2) standar Proses, 3) standar Kelulusan, 4) standar Pengelolaan, 5) standar Sarana dan Prasarana, 6) standar Pembiayaan, 7) standar Pendidik dan Tendik, dan 8) standar Penilaian (Depdiknas, 2005).

Berbagai program yang telah dilaksanakan oleh Kemdiknas melalui Direktorat Pembinaan SMA, dalam rangka mengakomodasi berbagai kebutuhan dan potensi daerah dalam penyelenggaraan Broad Base Education (BBE), kecakapan hidul (life skill), serta Pendidikan Berbasis Keunggulan Lokal (PBKL) di sejumlah SMA telah dilakukan monitoring dan evaluasi internal (Direktorat Pembinaan Sekolah Menengah Atas, 2010). Hasil monitoring dan evaluasi sebagai berikut.

Pertama, implementasi program BBE life skill SMA tahun 2002-2004 yang dikembangkan menjadi SMA Berbasis Keunggulan Lokal Kelautan (BKLK) tahun 2006, hampir seluruh kegiatan bersifat vokasional, sehingga belum diperoleh hasil optimal yang berkesinambungan. $\mathrm{Hal}$ ini disebabkan unsur pendidik dan tenaga kependidikan belum sepenuhnya memahami program tersebut, di samping itu, program pembelajarannya tidak menjadi bagian struktur kurikulum.

Kedua, supervisi terhadap 170 sekolah RSKM menunjukkan bahwa, 32.96\% sekolah yang telah melaksanakan PBKL, $4.71 \%$ berhasil amat baik, $8.82 \%$ baik, dan $19,41 \%$ cukup. Adapun sisanya $67 \%$ masih kurang, dan ini berarti masih diperlukan upaya untuk mendorong sekolah rintisan tersebut agar dapat melaksanakan PBKL secara tepat guna. 
Ketiga, supervisi terhadap 93 sekolah rintisan PBKL menunjukkan bahwa, 2.15\% sekolah berkategori Kurang dan $5.38 \%$ berkategori Cukup, berarti masih ada sekolah rintisan PBKL yang belum dapat melaksanakan PBKL seperti yang diharapkan. Pelaksana rintisan PBKL menunjukkan $86.02 \%$ dapat didorong untuk mencapai profil RSKM, 6.45\% kategori Siap SKM). Semua sekolah rintisan PBKL telah dapat melaksanakan KTSP (83.87\% kategori Baik, 8.60\% kategori Cukup, dan 7.53\% Kurang). $65.69 \%$ sudah melaksanakan PSB secara mandiri meskipun baru 2 (dua) SMA yang berkategori Baik dan belum ada yang berkategori Sangat Baik (Direktorat Pembinaan SMA, 2010).

Secara historis, Pemerintahan Kota Pekalongan dibentuk berdasarkan UndangUndang Nomor 16 Tahun 1950, selanjutnya dengan terbitnya Undang-Undang Nomor 18 Tahun 1965 Kota Pekalongan berubah sebutannya menjadi Kotamadya Dati II Pekalongan, kemudian terbit Peraturan Pemerintah Nomor 32 Tahun 2004 yang mengubah Kotamadya Dati II Pekalongan menjadi Kota Pekalongan (Pemerintah Kota Pekalongan, 2011).

Penyelenggaraan PBKL di Sekolah Menengah Atas Negeri (SMAN) 2 Pekalongan yang pada mulanya mendapat bantuan dari Direktorat Pembinaan Sekolah Menengah dan lintas dinas setempat (Dinas Perikanan), proses pembelajaran PBKL berjalan sesuai dengan yang diharapkan. Namun, dengan terjadinya banjir air rob (pasang air laut) menyebabkan proses pembelajaran terganggu. Kejadian banjir tersebut berlangsung seketika tanpa dapat diprediksi sebelumnya. Dampak banjir mengakibatkan kerusakan kolam ikan (tanggul pembatas) jebol, dan menjadikan proses pembelajaran terganggu. Akibatnya a) sebagian besar ikan keluar dari kolam cukup signifikan; dan b) proses pembelajaran yang telah disusun sesuai RPP tertunda, apalagi tanggul belum selesai diperbaiiki dan banjir air rob terjadi secara rutin/tahunan. Kondisi tersebut mengakibatkan pelaksanaan PBKL Kelautan di SMAN 2 Kota Pekalongan belum berjalan sesuai dengan tujuan penyelenggaraan PBKL. Pemahaman guru terhadap PBKL Perikanan masih kurang karena latar belakang pendidikan guru tidak sesuai dengan bidang yang diampunya. Di samping itu, bimbingan teknis berupa "penyuluhan perikanan" dari Dinas Perikanan Kota Pekalongan tidak berkelanjutan (akibat banjir air rob) juga mempengaruhi ketidaklancaran pembelajaran di sekolah. Kondisi inilah yang menjadi temuan monitoring dan evaluasi Direktorat Pembinaan SMA (2010) terhadap implementasi PBKL di SMAN 2 Pekalongan. Dengan demikian, penyelenggaraan PBKL Perikanan di SMAN 2 Pekalongan belum berjalan sebagaimana yang diharapkan. Hal ini antara lain disebabkan oleh kurang adanya pemahaman guru pengampu program PBKL perikanan yang sifatnya vokasi. Di samping itu, program pembelajarannya tidak menjadi bagian struktur kurikulum, sehingga guru pengampu harus menyusun silabus dan bahan materi ajar sendiri. Kurangnya pemahaman terhadap program PBKL diasumsikan antara lain kurang intensifnya penyelengaraan program sosialiasi dan koordinasi Direktorat Pembinaan SMA dengan warga sekolah (SMAN 2 Pekalongan) dan Komite Sekolah. Hal ini sejalan dengan pendapat Purwanto dan Sulistyastuti (2012) yang menyatakan bahwa beberapa program terobosan dari pemerintah pusat ke daerah seperti program Jaring Pengaman Sosial (JPS) dan Program Penanggulangan Kemiskinan Perkotaan (P2KP) dinilai kurang berhasil.

Faktor lain yang menyebabkan kurang optimalnya penyelenggaraan PBKL di SMAN 2 Pekalongan, antara lain: 1) proyek rintisan sekolah bertaraf internasional (RSBI) telah dinyatakan oleh Mahkamah Konstitusi melalui Surat Keputusan Nomor 5/PUU-X/2012 bahwa sekolah piloting RSBI tidak dapat dioperasikan lagi (kembali ke sekolah regular/sekolah biasa) hal ini berdampak pada keberlanjutan piloting PBKL; dan 2) bantuan dana operasional PBKL dari Direktorat Pembinaan SMA tidak berkelanjutan; dan 3) guru pengampu PBKL (perikanan) umumnya tidak sesuai dengan latar 
belakang pendidikan (mish match) sehingga menimbulkan masalah dalam perolehan sertifikasi guru.

Atas uraian latar belakang di atas, maka permasalahan yang dirumuskan yaitu, 1) bagaimana keberlanjutan (sustainability) pelaksanaan program PBKL di SMAN 2 Pekalongan? 2) bagaimana kebermanfaatan program PBKL terhadap peserta didik? dan 3) Bagaimana kebermanfaatan program PBKL terhadap nilai ekonomi bagi masyarakat di sekitar SMAN 2 Pekalongan?

Mengacu pada permasalahan, maka tujuan studi ini dimaksudkan untuk menganalisis: 1) keberlanjutan (sustainability) kebijakan pelaksanaan kebijakan program PBKL di SMAN 2 Pekalongan; 2) dampak program PBKL terhadap peserta didik SMAN 2 Pekalongan; dan 3) kebermanfaatan terhadap nilai tambah ekonomi bagi masyarakat di sekitar SMAN 2 Pekalongan.

\section{KAJIAN LITERATUR}

\section{Pendidikan Berbasis Keunggulan Lokal}

Keunggulan lokal merupakan salah satu potensi yang ada di setiap daerah yang dapat dijadikan bahan ajar kontekstual yang menarik untuk diajarkan di sekolah. Hal ini dikarenakan peserta didik merasa lebih memperoleh kesempatan untuk mengenal dan mengembangkan potensi dirinya terhadap bakat dan minat melalui kepedulian terhadap potensi lingkungan di daerahnya. Keberagaman potensi keunggulan daerah harus dilestarikan dan dikembangkan dengan tetap mempertahankan nilai-nilai luhur di dalamnya melalui pendidikan. Menurut Prihartini, 2014) melalui keunggulan lokal realisasi peningkatan nilai dari potensi daerah diharapkan menjadi produk atau jasa atau karya yang bernilai tinggi bersifat unik dan memiliki keunggulan kompettitif.

Tujuan penyelenggaraan PBKL antara lain agar peserta didik mengetahui keunggulan lokal daerah tempat mereka tinggal, memahami berbagai aspek yang berhubungan dengan keunggulan lokal tersebut. Dengan demikian, peserta didik mampu mengolah sumber daya, terlibat dalam pelayanan/jasa atau kegiatan lain yang berkaitan dengan keunggulan lokal, sehingga memperoleh penghasilan sekaligus melestarikan budaya, tradisi, dan sumber daya yang menjadi unggulan daerah, serta mampu bersaing secara nasional dan global (Wasino, 2008).

Ausubel (1978) dan Bruner (1977) dalam Sudrajat (2005), bahwa proses belajar dalam pendidikan akan menjadi lebih menarik dan menantang manakala peserta didik mengetahui apa manfaat dan makna dari pembelajaran untuk menghadapi berbagai persoalan kehidupan yang dihadapinya saat ini maupun masa mendatang. Suasana belajar yang menyenangkan (joyful learning) akan lebih bermakna apabila apa yang dipelajarinya ber-guna bagi kehidupannya kelak. Selama belajar, peserta didik mendapatkan bekal keterampilan (life skill) yang bermanfaat dan berharga untuk menghadapi serta mempertahankan kehidupannya (survive skill) di kemudian hari.

Sementara itu, Mulyasa (2005) menyatakan bahwa pendekatan pembelajaran kontekstual (Contextual Teaching and Learning) merupakan suatu konsep pembelajaran yang menekankan pada keterkaitan antara materi pelajaran dengan dunia nyata, sehingga para siswa mampu menghubungkan dan menerapkan kompetensi hasil belajar dalam kehidupan sehari-hari. Hal ini sejalan dengan Skripsi Diah Kusumaningsih dalam Upaya Meningkatkan Kemampuan Berpikir Kritis Siswa Kelas X-C SMA Negeri 11 Yogyakarta Melalui Pembelajaran Matematika dengan Pendekatan Contextual Learning: Perbandingan Trigonometri menunjukkan bahwa pembelajaran yang berkaitan dengan kehidupan nyata sangat berkesan bagi peserta didik (core.ac.uk/ download/pdf/1105973.pdf).

Contextual Teaching and Learning (CTL) merupakan suatu pendekatan pembelajaran yang menekankan pada proses keterlibatan siswa secara penuh untuk dapat menemukan materi yang dipelajari dan menghubungkannya dengan situasi kehidupan nyata, sehingga 
mendorong siswa untuk dapat menerapkannya dalam kehidupan mereka.

\section{Pemerintah dan Pemerintah Daerah}

Untuk menjaga keberhasilan program PBKL di SMA, perlu mendapat dukungan sepenuhnya dari pemerintah (pusat) dan pemerintah daerah serta masyarakat. Hal ini sebagai wujud tanggung jawab bersama antara pemerintah (pusat dan daerah), orang tua, dan masyarakat dalam hal pendidikan. Rintisan SMA model SKM-PBKL-PSB, merupakan program bersama antara pemerintah, pemerintah daerah (dinas pendidikan provinsi/kota), sekolah, dan masyarakat.

Pemerintah Pusat melalui Direktorat Pembinaan Sekolah Menengah, Direktorat Pembinaan SMA dan Pemda Kota Pekalongan telah membantu dana "pendamping" sebesar Rp 50.000.000/tahun sejak tahun 2008 sampai dengan tahun 2012. Sekolah penyelenggara PBKL mendapat bantuan dana dari Pemda Kota melalui Disdik Kota Pekalongan diperoleh sebesar Rp 20.000.000 yang diajukan melalui Rencana Anggaran Pendapatan dan Belanja Sekolah (RAPBS).

Pemilihan program PBKL di SMA perlu mempertimbangkan karakter masyarakat tempat mereka berdomisili. Masyarakat pesisir di Pekalongan merupakan sekumpulan masyarakat yang hidup bersama-sama mendiami suatu wilayah pesisir membentuk dan memiliki kebudayaan serta memiliki kekhasan terkait dengan ketergantungannya pada pemanfaatan sumber daya alam pesisir/pantai (Satria, 2005). PBKL berciri khas kedaerahan yang mencakup aspek ekonomi, budaya, teknologi informasi dan komunikasi, ekologi, dan lain sebagainya. Lebih lanjut, PBKL dapat diindikasikan dengan hasil bumi, kreasi seni, tradisi, budaya, pelayanan, jasa, sumber daya alam, dan sumber daya manusia yang menjadi keunggulan suatu daerah (Dwitagama, 2007). Dengan kata lain, disimpulkan bahwa keunggulan lokal merupakan suatu proses dan realisasi peningkatan nilai dari suatu potensi daerah sehingga menjadi produk/ jasa atau karya lain yang bernilai tinggi, bersifat unik dan memiliki keunggulan komparatif.

\section{Potensi Sumber Daya Alam}

Pekalongan memiliki sumber daya alam seperti industri/perusahaan pengolahan hasil laut (ikan asin, ikan asap, tepung ikan, terasi, sarden, dan kerupuk ikan), baik dalam skala besar maupun kecil (industri rumah tangga) serta pelabuhan perikanan terbesar di Pulau Jawa. Kepemilikan potensi di bidang perikanan menjadikan para pebisnis berpeluang melakukan usaha bisnisnya di Kota Pekalongan meliputi: 1) perikanan mini purse: a) perbengkelan kapal; b) perikanan milenium; c) transportasi perikanan; dan d) perikanan gill net; dan 2) perikanan pasca tangkap: a) pengolahan ikan asin, pindang, ikan segar, panggang; b) pengolahan rumput laut; c) cold strorage, pabrik es; d) terasi; d) pengolahan surimi; dan e) dendeng ikan dan kerupuk udang/ikan (BPMP2T Kota Pekalongan, 2014).

Beberapa potensi SDA di bidang perikanan meliputi ikan laut dan tawar, rumput laut, tambak, dan bidang kelautan. Potensi perikanan pasca tangkap yang ada terdiri atas usaha pengolahan ikan segar, ikan asin, ikan pindang, ikan panggang, surimi, rajungan, trasi, rumput laut, kerupuk ikan/udang dan ikan kaleng. Di samping itu, juga berkembang dengan baik usaha cold storage, pabrik es dan transportasi hasil perikanan. Semua produk perikanan pasca tangkap dimanfaatkan dan memiliki nilai jual yang tinggi. Kota Pekalongan memiliki Laboratorium Pembinaan dan Pengujian mutu hasil perikanan (LPPMHP) sebagai sarana pembinaan dan pengujian terhadap unit-unit processing, meliputi pemeriksaan dan pengujian terhadap hasil-hasil perikanan.

Selanjutnya, perikanan budidaya air tawar di Kota Pekalongan terdiri atas budidaya ikan konsumsi dan budidaya ikan hias. Jenis ikan konsumsi yang banyak dibudidayakan adalah ikan lele dan ikan nila. Budidaya ikan lele yang dilakukan oleh masyarakat mengalami per- 
kembangan yang signifikan karena permintaan konsumen dari waktu ke waktu bertambah tinggi. Kegiatan budidaya ikan hias di Pekalongan juga mengalami perkembangan, antara lain adanya pasar ikan hias dan asosiasi pecinta ikan hias pekalongan (APIHKAL) yang sering menyelenggarakan kontes dan ekspo baik lokal maupun nasional (Pemerintah Kota Pekalongan, 2011).

Budidaya air payau (tambak) mengalami perkembangan yang cukup berarti, di mana jenis "kultivan" yang dominan dibudidayakan yaitu ikan bandeng, udang, kepiting dan rumput laut. Rumput laut (gracillaria $s p$ ) masih dalam taraf uji coba, pertumbuhannya yang sangat prespektif untuk lebih dikembangkan. Perikanan budidaya di kota Pekalongan yang berkembang dengan baik dan memiliki potensi untuk dikelola secara lebih optimal terdiri atas budidaya ikan air tawar dan ikan air payau.

Penangkapan ikan dimaksudkan sebagai usaha penangkapan ikan di laut dengan kapal dan berbagai alat tangkap, baik dari jenis jaring maupun pancing. Jenis ikan yang ditangkap antara lain: kakap, tuna, lemuru, layur, cumicumi, kembung, tengiri dan lain-lain untuk ekspor maupun konsumsi sendiri dan industri lokal. Prospek pasar, pengembangan perikanan tangkap didukung oleh ketersediaan pelabuhan pendaratan ikan (PPI) dan tempat pelelangan ikan (TPI) yang telah dikenal oleh pedagang ikan di beberapa kabupaten sekitar Pekalongan sampai di luar provinsi dan pulau di Indonesia. Hasil diskusi dengan pihak DUDI melalui focus group discussion (FGD) mengungkapkan, bahwa permintaan ikan tangkap jauh lebih besar dibanding suplai ikan yang mendarat di PPI kota Pekalongan. Hal ini didukung oleh penelitian Tiarso (2012) terkait dengan potensi dan peluang pengembangan usaha perikanan tangkap di pantura Jawa Tengah yang menyatakan bahwa di sepanjang pantura Jawa Tengah memiliki potensi yang tinggi dalam menghasilkan ikan tangkap dan pemanfaatan sumber daya perikanan tangkap.

Di samping itu, berkaitan dengan potensi lokal pengelolaan perikanan (Herigal 2009) melakaukan studi Peningkatan Kebutuhan Pendidikana Kejuruan Untuk Mendukung Potensi Lokal Perikanan di Kecamatan Pangkalbalam dan Kecamatan Bukit Intan, menunjukkan bahwa potensi lokal perikanan di kedua kecamatan tersebut sangat tinggi dan keberadaan SMKN di lokasi tersebut sangat diperlukan dalam upaya meningkatkan nilai keekonomian melalui pengolahan perikanan.

Potensi SDA perikanan mendukung keberadaan SMAN 2 Pekalongan dalam menyelenggarakan PBKL kelautan/perikanan dengan tujuan agar peserta didik yang sebagian besar tidak melanjutkan pendidikannya ke jenjang yang lebih tinggi dapat mengenal keunggulan lokal di lingkungannya dan mengetahui dasardasar pengelolaan perikanan sehingga setelah lulus dari SMAN 2 Pekalongan mampu menghidupi dirinya (survive live) dengan kompetensi yang dimiliki di bidang perikanan.

Hasil penelitian terdahulu yang relevan seperti "Studi Evaluasi Kesiapan Melaksanakan Pendidikan Berbasis Keunggulan Lokal di Sekolah Menengah Atas Negeri 1 Praya Lombok Timur" menunjukkan bahwa sekolah penyelenggara PBKL telah siap melaksanakan dari aspek CIP (contex, input, dan product). Namun, dalam pelaksanaannya mengalami kendala antara lain dalam hal: a) pengelolaan program yang belum transparan; b) keterbatasan sarana dan prasarana pembelajaran, dan c) kualitas SDM masih kurang dalam memahami program PBKL (Ahsin, 2012). Upaya penanggulangan kendala dilakukan melalui pelaksanaan sosialisasi program PBKL secara optimal dengan melibatkan para pemangku kepentingan pengelolaan/ manajemen PBKL secara terbuka/transparan di samping meningkatkan kualitas SDM (guru) dan bermusyawarah dengan guru, komite sekolah, tokoh masyarakat, dinas terkait, pemda setempat sehingga masing-masing memiliki peran dan tanggung jawab sesuai dengan peran dan fungsinya (Ahsin, 2012). 


\section{METODE}

Studi ini merupakan studi kasus di SMA Negeri 2 Pekalongan yang mendeskripsikan pelaksanaan kebijakan pembelajaran berbasis keunggulan lokal di bidang perikanan. Teknik pengumpulan data dilakukan dengan cara wawancara, observasi dokumen, dan diskusi terfokus (focus group discussion). Penelitian dilaksanakan pada tanggal 9 sampai dengan 13 Juni 2015 di Sekolah Menengah Atas (SMA) Negeri 2 Pekalongan. Responden studi terdiri atas kepala sekolah, guru, tokoh masyarakat di bidang perikanan, komite sekolah, perwakilan dunia usaha dan dunia industri perikanan, Analisis deskriptif mencakup komponen pelaksanaan program pembelajaran berbasis keunggulan lokal termasuk ketersediaan sarana dan prasarana, ketersediaan pendidik, dan ketersediaan dana operasional, serta kebermanfaatan program PBKL bagi peserta didik maupun nilai tambah ekonomi (kesejahteraan) bagi masyarakat di lingkungan sekolah.

\section{HASIL DAN PEMBAHASAN}

\section{Keberlanjutan pelaksanaan program PBKL}

Setelah bantuan program PBKL dari Direktorat Pembinaan Sekolah Menengah Atas, Ditjen Mandikdasmen ke sekolah piloting dihentikan, maka program tersebut diserahkan kepada dinas pendidikan kabupaten/kota sesuai dengan kewenangan otonomi daerah. Pada tahap awal, kebijakan PBKL di kota Pekalongan diimplementasikan di sekolah yang telah dinilai memenuhi kategori sebagai sekolah mandiri (SKM), seperti di SMAN 2 Pekalongan. Selanjutnya, beberapa sekolah mengikuti untuk melaksanakan program PBKL sesuai dengan potensi sumber daya alam (SDA), potensi sumber daya manusia (SDM), potensi geografis, potensi budaya, dan potensi historis. Penetapan jenis PBKL di SMAN ditetapkan berdasarkan hasil analisis potensi kota Pekalongan yang kemudian disetujui oleh pemda setempat.

SMAN 2 Pekalongan mendapat bantuan dana operasional sebesar Rp 50.000.000/tahun (dari Direktorat Pembinaan Sekolah Menengah) dan
Rp 20.000.000 dari Pemerintah Daerah Pekalongan. Namun, bantuan dari pusat tidak berjalan sebagaimana mestinya sejak tahun ajaran 2008/2009, karena kebijakan program PBKL berawal dari pemilihan sekolah mandiri dan RSBI yang kemudian atas putusan Mahkamah Konstitusi Nomor 5/PUU-X/2012 sekolah RSBI tidak diperbolehkan beroperasi lagi.

Penerapan kebijakan PBKL memerlukan sinergi antara sekolah, guru, dan siswa agar siswa mampu mengatur waktu antara mempelajari persiapan materi tes formatif dan tes sumatif, materi ujian nasional, dan materi PBKL. Di samping itu, sangat diperlukan sinergi antara sekolah dengan masyarakat, dunia usaha dan dunia industri, birokrasi, untuk menunjang kebutuhan pendidik, sarana dan prasarana, serta dana operasional.

Tantangan penyelenggaraan program PBKL di SMAN 2 Pekalongan yang dominan yaitu adanya bencana air rob (air laut) tahunan yang selalu mengganggu proses pembelajaan. Kepala sekolah sebagai manajer lembaga pendidikan, dituntut untuk membenahi kondisi sarana dan prasarana kolam ikan manakala terjadi meluapnya "air rob" dari laut yang berjarak \pm 1 $\mathrm{km}$ dari sekolah. Apabila, terjadi air pasang (air rob), ikan pun keluar dari kolam, bahkan sekolah terkadang terpaksa diliburkan.

Informasi yang diperoleh dari hasil wawancara dengan kepala sekolah dan guru mengindikasikan bahwa pada tahun 2006 sekolah mendapat tawaran bantuan dana pendamping untuk melaksanakan $\mathrm{PBKL}$, dengan beberapa syarat antara lain: a) mengajukan proposal sebagai sekolah penyelenggara PBKL, b) $50 \%$ lulusan tidak melanjutkan pendidikan ke jenjang yang lebih tinggi (kuliah), c) lokasi sekolah berdekatan dengan potensi geografis, berjarak $1 \mathrm{~km}$ dari pantai. Atas pertimbangan tersebut, SMAN 2 Pekalongan ditunjuk sebagai sekolah PBKL berwawasan keunggulan kelautan/ perikanan. Sebagai persiapan awal, sekolah diberi masukan untuk membuat tambak sebagai media pembelajaran perikanan, dengan menyusun kurikulumnya sendiri. Dengan rincian kelas $X$ 
diberi materi pembelajaan wawasan pengairan kelautan, kelas XI diberi materi pembelajaan pembesaran ikan, dan kelas XII diberi materi pembelajaan pengolahan hasil pangan ikan. Kurikulum untuk ketiga materi pembelajaran dibuat sendiri, yang materinya tidak terintegrasi dalam suatu mata pelajaran tertentu, melainkan berdiri sendiri dengan alokasi waktu 2 jam/minggu yang diajarkan melalui keterampilan. Pada saat ini, hal itu menjadi masalah tersendiri karena kesulitan mencari guru yang betul-betul sesuai/ spesifik. Dari masalah tersebut SMAN 2 Pekalongan sempat di bantu oleh Dinas Perikanan Pekalongan. Sebagaimana dikatakan oleh Tuti Hartati salah satu Guru SMAN 2 Pekalongan, bahwa sekolah terkadang terkena banjir, sehingga ikannya habis keluar dari kolam. Guru tersebut mengambil inisiatif, yaitu mengajak teman-teman sesama guru yang spesialis mengajari pengolahan hasil pangan ikan untuk dibuat "nugget" (dari bahan dasar ikan dicampur dengan sukun dan labu).

Kepala sekolah menjelaskan bahwa sekolah beserta warga sekolah belum mampu mengatasi masalah gangguan pembelajaran jika terjadi banjir air rob. Dampak meluapnya air rob terhadap keberadaan kolam ikan selalu silih berganti. Menurutnya, masalah banjir akan dapat teratasi antara lain dengan meninggikan tembok pembatas kolam ikan untuk menghalangi masuknya air rob ke dalam kolam ikan dan melengkapi sejumlah pompa air untuk mengurangi debit ketinggian air yang masuk ke dalam kolam maupun halaman sekolah apabila terjadi banjir air rob. Upaya yang dilakukan pihak sekolah dalam mengurangi dampak meluapnya air rob lebih bersifat sementara. Penanganan yang dilakukan seharusnya secara tepadu antara sekolah dengan para pemangku kepentingan pendidikan (stakeholders). Seperti Dinas Pekerjaan Umum atau instansi lain yang terkait bersama pemerintah daerah "turun tangan" dalam mengatasi masalah banjir air rob. Sudah menjadi keniscayaan bahwa hal ini merupakan tanggung jawab bersama antara sekolah dengan para pemangku kepentingan pendidikan di kota
Pekalongan. Sampai sekarang, SMAN 2 Pekalongan belum dapat menyelesaikan penanganan banjir air rob. Hal ini didukung oleh hasil FGD baik pernyataan guru maupun kepala sekolah sebagai berikut.

"Permasalahan terkait dengan banjir air rob, kami memang belum mampu untuk mengatasi masalah banjir, karena sekolah kami hanya terkena dampaknya. Dampak tersebut antara lain jika terjadi pasang air rob masuk ke sekolah, proses belajarmengajar sementara waktu diliburkan sampai air laut surut. Kemudian, kondisi kolam ikan terlihat seperti hamparan laut tanpa terlihat tembok pembatas kolam sehingga ikannya berhamburan keluar kolam. Mestinya, masalah banjir air rob ditanggulangi bersama oleh instanassi terkait (Dinas Pekerjaan Umum, Dinas Pendidikan, dinas lain yang menangani masalah bencana alam, dan pemerintah daerah setempat (guru SMAN 2 Pekalongan)"

Menurut kepala sekolah, "kami di SMAN 2 lebih memperhatikan penanganan biaya operasional pembelajaran PBKL, karena keberadaaan kolam ikan sebagai laboratorium pembelajaran anak-anak, maka anggaran dari sekolah kita dimasukkan untuk itu. Itu pun hanya untuk biaya praktikum karena praktikumnya bermacammacam dan terus-menerus, adakalanya ada yang dibiayai dan terkadang biaya dari anak-anak. Untuk benih itu dibiayai, jadi karena kelas XI juga ada benih, biaya benih diambilkan sebagian dari dana bantuan dari provinsi sebesar Rp 20.000.000/tahun. Kemudian ada bantuan biaya dari komite sekolah untuk biaya pembelian pakan, dan tekadang dari peserta didik. Biaya pembesaran ikan telah kami berikan informasi dan arahan seminggu sebelum pelaksanaan praktik karena peserta didik harus mengumpulkan uang rata-rata mencapai Rp 500.000 untuk setiap pembelian pakan. Biaya pakan kadang-kadang dapat dari hasil jual ikan waktu musim panen. Panen ikan 
dapat diharapkan manakala frekuensi terjadinya air pasang rob jarang terjadi dalam kurun waktu tertentu".

"Alhamdulillah, tahun ini (2015) banjir robnya tidak sampai meluap masuk ke sekolah dan kolam ikan, sehingga kami dapat memanen ikan. Hasil panen ikan (walaupun ikan belum sampai besar) laku dijual di pasar, seharga Rp15.000/kg. Penjualan ikan bulan lalu hanya mencapai Rp 150.000, karena kerambanya banyak yang berlubang (bolong), dan kondisi jaring (net) keramba rusak dimakan usia dan belum diperbaiki secara menyeluruh". Menurut Walikota Pekalongan, rencana penanggulangan banjir air rob, akan dilakukan koordinasi penanganannya dengan instansi lain terkait (dinas PU, dan lain-lain), sehingga sekolah dapat melaksanakan kegiatan sebagaimana mestinya".

"Untuk penanggulangan kerusakan kolam ikan dan jaring keramba terus terang masih belum terealisasi seluruhnya, untuk sementara saya masih berkonsentrasi dengan kondisi sekolah yang membutuhkan pemikiran penanggulangan bencana air rob. Jadi konsentrasinya saya itu masih ke sarana-prasarana yang pokok yaitu ketersediaan sarana prasarana pembelajaran. Tenaga pikiran saya masih terkonsentrasi untuk pembelajaran yang tahun lalu kena dampak banjir, sehingga kita harus menaikkan tembok pembatas tambak secara bertahap agar tidak terkena luapan banjir lagi. Kalau masalah kolam tambak dan perangkatnya, dengan senang hati kami kalau masalah ini disampaikan ke Direktorat Pembinaan SMA Jakarta untuk memperoleh bantuan anggaran perbaikan sarana prasarana yang kami perlukan. Dana bantuan, kami memang sering mendapatkan hampir setiap tahun, tapi karena SMAN 2 setiap tahunnya terkena musibah bencana air rob, maka biaya operasionalnya selalu kurang mencukupi untuk operasional PBKL Perikanan".
Konsep Pendidikan Berbasis Keunggulan Lokal (PBKL) di SMA dan SMA Berbasis Keunggulan Lokal Kelautan di sejumlah SMA juga belum memperoleh hasil yang optimal dan tidak berkesinambungan (Direktorat Pembinaan SMA, 2010). Hal ini disebabkan unsur pendidik dan tenaga kependidikan belum sepenuhnya memahami program tersebut. Di samping itu, program yang dilaksanakan tersebut bukan menjadi bagian dari struktur kurikulum dan pembelajaran di sekolah. Sampai saat ini, kebijakan PBKL Kelautan di SMAN 2 Pekalongan masih menyisakan masalah permanen yaitu peninggian tembok batas kolam yang cukup luas belum dilakukan dan dana rutinitas perawatan perangkat kolam belum dialokasikan, sehingga fungsi kolam sebagai media pembelajaran belum berfungsi secara optimal. Akibatnya, pengetahuan dan kompetensi/keterampilan peserta didik belum dapat dicapai sepenuhnya pada setiap tahapan kompetensi dasar (KD). Kepala sekolah juga menuturkan bahwa dalam pembelajaran praktik program PBKL perikanan secara psikologis terdapat perbedaan "sikap" antara peserta didik laki-laki (lebih aktif) dan perempuan (kurang aktif) manakala melakukan praktik pembelajaran perikanan masuk ke dalam kolam ikan.

Meskipun masih sering terjadi banjir air rob dan masalah ini belum terpecahkan, tidak menghalangi niat kepala sekolah dan warga sekolah serta komite sekolah untuk tetap melanjutkan kebijakan program PBKL sebagai salah satu keunggulaan lokal Kelautan/Perikanan sembari berusaha bersama dan melakukan koordinasi dengan instansi terkait untuk mengurangi hambatan tersebut. Keberlanjutan program PBKL Kelautan/Perikanan di SMAN 2 Pekalongan didukung prinsip manajemen berbasis sekolah (MBS) sebagai bentuk otonomi sekolah dalam mengembangkan program-program kegiatan inovasi di sekolahnya. Menurut kepala sekolah, keberlanjutan (sustainability) program ini tentunya sangat tergantung dari kebijakan kepala sekolah (baru) manakala suatu saat terjadi pergantian kepala sekolah, termasuk ada 
tidaknya dukungan dari pejabat birokrasi di tingkat pemda setempat dan wakil rakyat (anggota DPRD/komisi yang membidangi bidang pendidikan) secara harmonis dalam mewujudkan "ekosistem pendidikan" di Kota Pekalongan.

\section{Kebermanfaatan Program PBKL bagi Peserta Didik}

Keberhasilan program pembelajaran PBKL Perikanan sangat ditentukan oleh kualitas pendidik (guru) dan iklim kelas (classroom climate) yang kondusif serta ketersediaan sarana dan prasarana yang memadai sesuai dengan standar yang dipersyaratkan (SNP). Kegiatan pembelajaran akan berkualitas dan bermakna bagi siswa apabila didukung oleh guru yang profesional. Di samping itu, kualitas pembelajaran juga dapat dipengaruhi oleh siswa yang berkualitas (memiliki kecerdasan, memiliki motivasi belajar yang tinggi dan sikap positif dalam belajar)

Kualitas pembelajaran dapat diukur dengan menggunakan beberapa indikator keberhasilan pembelajaran. Keberhasilan proses pembelajaran merupakan kolektivitas peran guru, siswa, sarana pembelajaran, lingkungan kelas, dan budaya kelas. Semua indikator tersebut harus saling mendukung dalam sebuah sistem pembelajaran yang berkualitas. Untuk mengetahui tingkat kualitas pembelajaran dalam pembelajaran, maka perlu diketahui dan dirumuskan indikator-indikator kualitas pembelajaran. Menurut Morrison, Mokashi dan Cotter (2006) dalam Aman dan Dyah (2008) telah dirumuskan sebanyak 44 indikator kualitas pembelajaran yang kemudian direduksi menjadi sepuluh indikator. Kesepuluh indikator kualitas pembelajaran tersebut meliputi: 1) Rich and stimulating physical environment; 2) Classroom climate condusive to learning; 3) Clear and high expectation for all student; 4) Coherent, focused instruction; 5) Thoughtful discourse; 6) Authentic learning; 7) Regular diagnostic assessment for learning; 8) Reading and writing as essential activities; 9) Mathematical reasoning; 10) Effective use of technology.
Berdasarkan indikator-indikator di atas, indikator kualitas pembelajaran perikanan direduksi menjadi 5 indikator, yang dianggap memiliki peranan cukup besar dalam menentukan kualitas pembelajaran. Kelima indikator tersebut meliputi: 1) kinerja guru dalam kegiatan belajar mengajar di kelas; 2) sarana pembelajaran perikanan; 3) menggunakan teknologi pembelajaran yang tepat; 4) sikap siswa terhadap pelajaran perikanan; dan 5) motivasi belajar siswa (Aman dan Dyah, 2008).

Pembelajaran di SMA Negeri 2 kota Pekalongan tidak selalu dapat memenuhi kelima indikator tersebut dikarenakan keberadaan guru, siswa, sarana dan prasarana dan iklim kelas yang kurang kondusif dalam arti iklim sekolah manakala terjadi banjir air rob sebagai salah satu faktor dominan yang mempengaruhi pembelajaran di sekolah.

Namun demikian, keunggulan lokal di SMAN 2 Pekalongan diinspirasi oleh berbagai potensi, antara lain potensi sumber daya alam (SDA). Konsep PBKL pada hakikatnya didukung oleh berbagai legal formal yang terkait. Oleh karena itu, pemberian materi PBKL berorientasi pada keperluan peserta didik SMAN 2 Pekalongan, antara lain agar: a) peserta didik mengetahui keunggulan lokal di daerahnya khususnya perikanan; b) peserta didik memahami berbagai aspek yang berhubungan dengan keunggulan lokal di daerahnya; dan c) peserta didik mampu mengolah sumber daya yang dapat berkontribusi dalam pelayanan/jasa atau kegiatan lain yang berkaitan dengan keunggulan lokal; d) setelah lulus peserta didik dapat menghidupi dirinya dengan memperoleh penghasilan, sekaligus melestarikan budaya, tradisi, dan sumber daya yang menjadi unggulan daerah, serta mampu bersaing secara nasional.

Untuk mewujudkan kebutuhan peserta didik, SMAN 2 Pekalongan dilengkapi dengan berbagai sarana dan prsarana sebagai berikut. Sejak tahun pelajaran 2006/2007 SMAN 2 Pekalongan telah mempunyai fasilitas tambak yang dikelola oleh guru dan siswa. Di sekitar sekolah, terdapat sarana dan prasarana yang relevan yaitu tempat 
pelelangan ikan (TPI). Pada tahun pelajaran 2008/2009, SMAN 2 Kota Pekalongan ditunjuk sebagai Rintisan Sekolah Kategori Mandiri (RSKM). Bangunan sekolah memiliki luas tanah 3 hektar yang masih dalam kondisi baik, dilengkapi dengan sarana dan prasarana pembelajaran yang mencukupi untuk menunjang kegiatan belajar-mengajar. Ketersediaan sarana dan prasarana pembelajaran di SMAN 2 Pekalongan sebagaimana tertera pada Tabel 1.

Fasilitas sekolah secara umum dapat berpengaruh terhadap kenyamanan proses belajar-mengajar dan aktivitas lain yang ada di dalamnya. Secara rinci, fasilitas-fasilitas yang ada di SMAN 2 Pekalongan terdiri atas:

1. Ruang Kepala Sekolah, dilengkapi dengan seperangkat sarana pendidikan antara lain, satu unit komputer, kursi dan meja tamu. Ruang kepala sekolah ini merupakan ruang kerja terpisah dari ruang yang lain. Adapun ruang kerja tersendiri yang disediakan untuk meningkatkan profesionalisme kerja dan mempermudah konsentrasi kerja.

2. Ruang Guru, dengan luas kurang lebih $96 \mathrm{~m}^{2}$ dilengkapi dengan seperangkat komputer dan asesoris/komponennya.

3. Ruang Tata Usaha, dengan luas $42 \mathrm{~m} 2$, berfungsi sebagai pusat administrasi sekolah.

4. Ruang Perpustakaan, mempunyai luas kurang lebih $76 \mathrm{~m} 2$. Ruang ini mempunyai tata ruang udara yang memadai, sehingga udara dan cahaya dapat bertukar dengan normal. Perpustakaan ini memiliki beberapa buah almari, rak buku yang cukup besar

Tabel 1 Sarana Pemebelajaran SMAN 2 Pekalongan

\begin{tabular}{ccccc}
\hline No & Ruang Kelas & Jml. Ruang & Jml.siswa/kelas & Keterangan \\
1 & $\mathrm{X}$ & 8 & 30 & Kelas Bersama \\
2 & $\mathrm{XI}$ & 8 & 30 & IPA-IPS masing-masing 4 ruang \\
3 & $\mathrm{XII}$ & 8 & 30 & IPA-IPS masing-masing 4 ruang \\
4 & Jml total ruang & 24 & 120 & 720 \\
\hline
\end{tabular}

Sumber: SMAN 2 Kota Pekalongan, 2014.

Tabel 2 Ketersediaan Prasarana SMAN 2 Pekalongan

\begin{tabular}{clcll}
\hline No & \multicolumn{1}{c}{ Ruanq } & Jumlah & Kondisi & Keteranqan \\
\hline 1 & Kepala Sekolah & 1 & Baik & \\
2 & Tata Usaha & 1 & Baik & \\
3 & Guru & 1 & Baik & \\
4 & Kelas & 24 & Baik & Fisika, Bioloqi, Kimia \\
5 & Laboratorium IPA & 3 & Baik & \\
6 & Laboratorium Bahasa & 1 & Baik & \\
7 & Laboratorium Komputer & 2 & Baik & \\
8 & Perpustakaan & 1 & Baik & \\
9 & Multimedia & 1 & Baik & \\
10 & Musholla & 1 & Baik & \\
11 & OSIS & 1 & Baik & \\
12 & Olahraga & 1 & Baik & \\
13 & Koperasi & 1 & Baik & \\
14 & U K S & 1 & Baik \\
15 & B K & 1 & Baik & \\
\hline & & & & \\
\hline
\end{tabular}

Sumber: SMAN 2 Kota Pekalongan, 2014. 
dan beberapa meja kursi untuk membaca. Buku-buku yang tersedia mayoritas bukubuku pengembangan untuk meningkatkan pengetahuan peserta didik berkenaan dengan ilmu yang sedang dipelajari. Meja kursi yang berfungsi sebagai tempat membaca berada di tengah-tengah dan rakrak buku di sebelah meja kursi membaca.

5. Ruang Laboratorium terdiri atas Laboratorium kimia, fisika dan biologi. Laboratorium fisika dan biologi saling berdampingan terletak di sebelah ruang multimedia dan terpisah dengan laboratorium kimia yang terletak di sebelah ruang multimedia. Sebagai sarana penunjang pelajaran kimia, fisika dan biologi, SMAN 2 Pekalongan menyediakan laboratorium untuk mata pelajaran kimia, fisika dan biologi dengan luas ruangan masing-masing sebesar $76 \mathrm{~m} 2$. Peralatan yang terdapat di laboratorium kimia sudah cukup memadai. Meskipun laboratorium sudah cukup baik akan tetapi pemanfaatannya masih sangat kurang. Hal ini dikarenakan apabila akan melakukan praktikum memerlukan persiapan yang lama. Fasilitas yang ada dalam laboratorium komputer meliputi komputer, headphone, dan tape recorder. Laboratorium Bahasa yang ada di SMAN 2 Pekalongan digunakan sebagai penunjang dalam proses belajar Bahasa Inggris khususnya listening. Fasilitas yang terdapat dalam laboratorium bahasa yaitu, komputer, headphone, dan tape recorder.

6. Ruang OSIS, digunakan sebagai tempat untuk penyimpanan perlengkapan upacara, di dalamnya terdapat 14 meja kerja dan satu unit komputer.

7. Ruang BK dan UKS, memiliki luas $28 \mathrm{~m}^{2}$ merupakan salah satu wadah yang digunakan untuk membantu peserta didik dalam meyelesaikan masalah pribadi, menggali segala potensi yang ada agar dapat dikembangkan dan diaktualisasikan dalam kehidupan nyata. Fasilitas dalam ruang $\mathrm{BP} / \mathrm{BK}$ dilengkapi dengan ruang tamu, lemari untuk menyimpan data, dan meja kursi untuk konsultasi peserta didik. Program BP meliputi seluruh kegiatan bimbingan dan penyuluhan yang berupa jenis-jensis pelayanan dan berbagai pendukung lainnya. Bentuk-bentuk layanan BP/BK yakni layanan orientasi, layanan informasi, layanan penempatan/penyaluran, layanan pembelajaran, layanan konseling perorangan, layanan konseling kelompok dan layanan bimbingan kelompok. Di SMAN 2 Pekalongan kasus atau masalah yang sering ditangani oleh bagian BK yaitu peserta didik yang datang terlambat. Peserta didik yang terlambat sekali dikenakan hukuman untuk membersihkan lingkungan kelas, sedangkan yang lebih dari sekali mendapat teguran dan surat peringatan. Ruang UKS terdapat di sebelah paling timur dari bangunan yang berada di depan perpustakaan dan dapat dimanfaatkan oleh peserta didik yang membutuhkan perawatan kesehatan di sekolah karena terdapat seorang dokter yang membantu untuk menangani masalah kesehatan dari masyarakat SMAN 2 Pekalongan.

8. Ruang Kelas, terdiri atas 24 ruang kelas untuk kelas X, XI, dan XI. Tiap ruang memiliki interior dan warna yang berbeda-beda sehingga peserta didik lebih nyaman dalam belajar. Fasilitas yang dapat ditemukan dari masing-masing ruang kelas meliputi: meja dan kursi guru sebanyak 1 pasang, meja dan kursi murid sebanyak jumlah peserta didik yaitu \pm 20 pasang, 1 buah white board, 1 speaker/pengeras suara, dan 1 buah $L C D$ yang terpasang di setiap kelas.

Selain itu, iklim sekolah (school climate) dan keberadaan guru serta peserta didik telah tercipta dalam suasana yang harmonis, kondusif, dan edukatif. Berbagai kegiatan di sekolah, baik kegiatan intra maupun ekstra berjalan sesuai dengan program yang dijadwalkan. Hal ini sebagai salah satu indikator adanya hubungan yang harmonis antara kepala sekolah dan guru. Interaksi sosial antara guru dalam keseharianya 
di sekolah melalui pembiasaan saling tegur-sapa, saling mengingatkan, dan mengajak kebaikan sebagai insan yang bermartabat.

Interaksi sosial antara siswa yang satu dengan siswa lainnya, juga terjalin dengan baik. Di dalam kelas pun mereka terlihat kompak, bersahabat, dan saling membantu dalam keperluan pembelajaran dan kebaikan. Selain itu, interaksi yang mereka bentuk tidak hanya dengan sesama siswa satu kelas tetapi dengan siswa lintas kelas dalam lingkungan sekolah.

Interaksi guru dengan siswa cukup baik contoh, apabila siswa bertemu guru, siswa akan menyapa guru dan mencium tangan guru. Begitu juga guru, akan mengajak siswa-siswanya untuk berkolaborasi dalam membicarakan soal pembelajaran di waktu jam istirahat, dan bahkan masalah aktual sosial kemasyarakatan yang sedang hangat. Guru akan menegur dan memberi sanksi bagi siswa yang melanggar peraturan sekolah. Hubungan guru dengan staf tata usaha dan warga sekolah lainnya tercipta dengan harmonis. Hal ini terlihat antara guru dengan staf tata usaha yang saling menyapa dan adanya komunikasi lewat fasilitas sekolah seperti microphone. Hal ini memudahkan guru untuk berinteraksi dengan staf tata usaha maupun dengan siswa, seperti memberikan informasi yang saling diperlukan.

Berdasarkan pengamatan dan wawancara dari berbagai pihak warga sekolah mengindikasikan bahwa iklim sekolah (school climate) di SMAN 2 Pekalongan telah terjadi interaksi sosial baik itu kepala sekolah-guru, guru-guru, siswa-siswa, guru-siswa, dan guru-staf tata usaha, dengan menjunjung prinsip saling menghargai dan bergotong-royong dalam menciptakan iklim sekolah yang lebih kondusif dan edukatif (SMAN 2 Kota Pekalaongan, 2014).

Namun demikian, para pendidik PBKL di SMAN 2 Pekalongan berkaitan dengan masalah sertifikasi guru menunjukkan masih belum tuntas. Hal ini dikarenakan latar belakang pendidik belum sesuai dengan mata pelajaraan yang diampunya (miss match). Dalam masalah ini untuk mengatasinya, dilakukan dengan merekrut guru tambahan (honor). Masalah sertifikasi guru ada dua klasifikasi, yaitu K1 (konsentrasi 1) dan K2 (konsentrasi 2). Untuk K1 diperuntukkan bagi guru yang sudah terlanjur menjadi guru dengan status PNS, namun mengampu mata pelajaran yang tidak sesuai dengan latar belakang program studi (mis match). Adapun kategori K2, bagi guru harus sesuai dengan kompetensi kualifikasi pendidikan (S1/D4) dengan mata pelajaran yang diajarkan sehingga dapat mengikuti uji sertifikasi. Bagi guru pengampu mata pelajaran kelompok produksi dan tidak sesuai dengan mata pelajaran yang diampunya maka kebijakan sekolah, guru diberi kesempatan untuk "alih fungsi" sesuai dengan minat dan penyesuaian tugas. Bagi guru yang belum memenuhi persyaratan pendidikan berkualifikasi S1 wajib menempuhnya karena dipersyaratkan oleh Undang-Undang Republik Indonesia Nomor 14 Tahun 2005 bahwa kualifikasi pendidikan bagi pendidik sekurangkurangnya berkualifikasi S1. Hasil diskusi terpimpin (focus group discussion) mengindikasikan masih adanya masalah dalam pelaksanaan sertifikasi guru yang mengajar mata pelajaran PBKL perikanan, yaitu konsentrasi satu (K1) dan konsentrasi dua (K2).

Tahun 2006 sekolah mendapat tawaran dana pendamping untuk melaksanakan PBKL melalui surat edaran dengan mengajukan proposal yang syarat untuk menjadi sekolah PBKL adalah $50 \%$ siswanya tidak melanjutkan pendidikan ke jenjang yang lebih tinggi (kuliah), berdekatan dengan potensi geografis yaitu lokasi SMAN 2 berjarak $1 \mathrm{~km}$ dari pantai. Atas pertimbangan itu, maka SMAN 2 Pekalongan ditunjuk sebagai sekolah PBKL berwawasan keunggulan Kelautan. Sekolah ini diberi doktrin untuk membuat tambak, sehingga menyusun kurikulum sendiri. Kelas $X$ diberi materi pembelajaran Wawasan Pengairan Kelautan, kelas XI diberi materi pembelajaran Pembesaran Ikan, dan kelas XII diberi materi pembelajaran Pengolahan Hasil Pangan Ikan.

Kurikulum untuk ketiga materi pembelajaran tersebut dibuat sendiri dan di SMA Negeri 2 materi tersebut tidak terintegrasi, tetapi terdiri 
2 jam khusus untuk Mata Pelajaran Kelautan, sebagai keterampilan dan bukan muatan lokal (mulok). Dengan spesifikasi seperti itu timbul kesulitan mencari guru yang sesuai. Seorang guru menjelaskan bahwa sebelumnya sekolah dibantu oleh Dinas Perikanan Darat Pekalongan. Agar hasil panen dapat dimanfaatkan sebelum adanya banjir rob, maka guru tersebut mengajak teman-teman guru yang spesialis mengajarkan pengolahan ikan untuk dibuat nugget dengan bahan dasar ikan dicampur dengan sukun dan labu.

Jenis ikan yang dibesarkan antara lain patin, nila dan berganti-ganti. Akhirnya, untuk pengolahan anak-anak membeli ikan dan ini merupakan kreativitas mereka. Dengan demikian, dibutuhkan guru yang bisa mengajar, karena guru yang ada sudah penuh jam mengajarnya, sampai mencapai 35 jam/minggu. Kesulitan yang ada yaitu mencari guru pengajar yang sesuai dengan bidang keahliannya. Kelas XI diberi pembelajaran Pembesaran Ikan, sekaligus anak-anak berrekreasi karena mereka akan memanen. Hasil panen dijual di pasar dan guru. Karena keterbatasan dana operasionalnya, sekolah ingin belajar ke Jatiluhur untuk mendalami keramba apung untuk diimplementasikan di SMA Negeri 2 Pekalongan. SMAN 2 Pekalongan sudah memiliki tambak yang cukup luas tapi belum dimaksimalkan. Ketika bantuan dari pusat diperoleh, sekolah membuat tambak yang besar sekali untuk membesarkan ikan. Setelah bantuan dari pusat berhenti dan tidak ada biaya perawatan tambak, diambil langkah menggunakan keramba dan membuat jaring yang apung. Kelemahan sekolah adalah bahwa belum dibangun tembok \pm 120 meter dan pemancing dari luar wilayah sekolah masuk, namun status tanah sudah milik sekolah. Untuk Kurikulum tahun 2013 (Kurtilas), materi kelautan masuk dalam KTSP, kemudian mengiplementasikan Kurtilas selama 1 semester. Pada saat menerapkan kurtilas 1 semester, itu guru yang ada diganti karena guru prakarya diambil dari guru Teknologi Informasi Komunikasi (TIK).
Hasil pembelajaran praktik PBKL di SMAN 2 Pekalongan masih dalam taraf pengenalan dasardasar membudidayakan ikan air tawar (tambak) seperti memberi pakan (makanan ikan), membersihkan keramba pada kurun waktu tertentu. Keuntungan dari pembelajaran tersebut antara lain siswa mengenal cara: a) membudidayakan ikan tambak; b) cara membesarkan ikan, dan c) mengelola hasil pangan dari bahan dasar ikan yang dikonsumsi oleh masyarakat.

Pelaksanaan program PBKL Perikanan di SMAN 2 Pekalongan secara teoretik didukung oleh pendekatan pembelajaran contextual teaching learning, sebagaimana mengutip pendapat Ausubel dan Bruner (dalam Sudrajat 2005). Dalam proses pembelajaran, akan lebih menarik dan menantang manakala peserta didik mengetahui manfaat dan makna dari pembelajarannya. Suasana belajar yang memberikan suasana menyenangkan (joyful learning) dikaitkan dengan potensi, bakat, minat, dan hobi peserta didik akan lebih bermakna jika apa yang dipelajari berguna bagi kehidupan di masa mendatang. Selama belajar, peserta didik mendapatkan bekal keterampilan (life skill) yang diprediksikan bermanfaat dan berharga untuk menghadapi dan mempertahankan kehidupannya (survive skill) di kemudian hari.

Penerapan pengelolaan pendidikan berbasis keunggulan lokal ini dapat membekali kompetensi peserta didik sebagai keterampilan hidup (life skill). Pada hakikatnya, pendidikan adalah proses inkubasi peserta didik sebelum terjun ke masyarakat. Hal ini berarti bahwa ketika dalam proses pendidikan, peserta didik sudah dikenalkan dengan keunggulan lokal dan memahami terkait potensi dan permasalahan di daerahnya, sehingga mereka akan siap untuk bertahan hidup di masyarakat.

Pendekatan pendidikan berbasis kearifan lokal dapat mendorong lahirnya kreativitas baru yang cemerlang dan spektakuler. Ke depan diharapkan dapat melahirkan entrepreuner profesional yang mampu menciptakan dan memanfaatkan peluang untuk mendulang 
keuntungan melalui jalur wirausaha/bisnis, baik secara individu maupun kelompok/kolektif di berbagai tingkatan (usaha kecil dan menengah). Program PBKL perikanan dapat mendorong lulusan SMAN 2 Pekalongan mampu melakukan komunikasi dan kerja sama dengan pebisnis di bidang perikanan manakala mereka terjun ke masyarakat. Dengan demikian, terjadi interaksi dan harmonisasi dalam ekosistem pendidikan di daerah karena terjadi interaksi saling membutuhkan antara sekolah/lulusan dengan berbagai institusi di masyarakat/DUDI. Hal ini terinsiprasi oleh hasil penelitian Lena (2010) tentang Peranan SMK Kelautan/Perikanan dalam meningkatkan sumber daya manusia kaitannya dengan ketahanan keluarga. Dari hasil penelitian diketahui bahwa lulusan SMK Kelautan dan Perikanan dapat diterima dengan mudah dan mampu bekerja di bidangnya. Kondisi seperti ini, dapat meningkatkan kesejahteraan masyarakat yang pada akhirnya dapat meningkatkan ketahanan pribadi/keluarga bagi para lulusannya.

Secara nasional, Nota Kesepahaman (MoU) antara Kemendikbud dengan Menko Maritim bertekad untuk mengoptimalkan SMK Perikanan dan Kelautan untuk menyiapkan sumber daya manusia dalam rangka pembangunan kemaritiman di Indonesia. Hal ini merupakan sebuah terobosan kebijakan di bidang pendidikan vokasi sekaligus mengangkat eksistensi potensi kemaritiman/perikanan yang merupakan salah satu keunggulan lokal di beberapa daerah pesisir (Iqbalon, 2015). Di samping itu, Menko Kemaritiman dan Mendikbud sepakat untuk menetapkan 10 SMK Perikanan dan Kelautan Unggulan sebagai SMK Percontohan. Kesepuluh SMK tersebut berlokasi di wilayah Jawa Barat, Jawa Tengah, Jawa Timur, Sulawesi Selatan, Nusa Tenggara Barat, Kalimantan Timur, Maluku, Tual dan Sulawesi Utara. SMK Percontohan di bidang kelautan/perikanan tidak hanya sebagai sekolah percontohan pada satuan sekolah menengah kejuruan, namun juga sebagai Pembina SMA PBKL.
PBKL di SMA tidak sama dengan program Kelautan/Perikanan (Kemaritiman) yang dilaksanakan di SMK. Namun hal tersebut dapat dianalogkan bahwa bidang Kelautan/Perikanan yang diwujudkan sebagai keunggulan lokal di suatu daerah, notabene dapat diadopsi dan dimodifikasi dari aspek kedalaman materi melalui program PBKL di SMA, minimal pengetahuan dan keterampilan dasar diintegralkan dalam pembelajaran PBKL Kelautan/Perikanan. Dengan kata lain, pembelajaran PBKL Kelautan/Perikanan di SMA lebih memberikan pengetahuan dan keterampilan dasar di bidang perikanan untuk keperluan kehidupan dirinya apabila peserta didik terjun ke masyarakat. Sebaliknya, di SMK lebih memberikan sejumlah kompetensi dasar (KD) untuk menyiapkan lulusannya bekerja di bidang industri perikanan.

\section{Kebermanfaatan Program PBKL bagi Masyarakat}

Pengelolaan pendidikan berbasis keunggulan lokal merupakan terobosan progresif dunia pendidikan dalam membangkitkan potensi daerah yang bermanfaat bagi masyarakat sekitar. Program PBKL memiliki keunggulan yaitu relevansi pendidikan dengan dunia nyata, di mana pendidikan berbasis keunggulan lokal dapat mendekatkan dunia pendidikan yang selama ini diklaim elitis dengan problem sosial yang populis.

Sebagai indikator, panyelenggaraan PBKL Kelautan/Perikanan belum memiliki dampak yang berarti bagi masyarakat, khususnya di bidang pengolahan makanan yang terbuat dari bahan dasar ikan, seperti sosis dan bakso. Keberhasilan program PBKL Perikanan tidak sekadar membekali peserta didik melalui pembelajaran pengetahuan dan keterampilan pengelolaan ikan. Masyarakat kota Pekalongan terimbas oleh pembelajaran PBKL Perikanan sebagai motivasi untuk mengembangkan keunggulan lokal perikanan sekaligus melestarikan budaya dan tradisi pengelolaan ikan serta pengembangan pengelolaannya. Dengan demikian, masyarakat kota Pekalongan mampu bersaing di tingkat lokal 
dan regional di bidang wirausaha (home industry) atau industri perikanan.

Keberadaan keunggulan lokal perikanan di sekitar SMAN 2 Pekalongan belum memberikan nilai tambah (ekonomi) bagi masyarakat yang bermukim di sekitar sekolah sebagai dampak langsung akibat penyelenggaraan program PBKL Kelautan di SMAN 2 Pekalongan. Nilai tambah ekonomi bagi masyarakat dalam konteks ini dimaksudkan adanya peningkatan penghasilan atau kesejahteraan sebagai dampak dari penyelenggaraan PBKL Perikanan di SMAN 2 Pekalongan yaitu bahwa mata pencarian masyarakat di sekitar sekolah. Pengaruh yang sangat signifikan adalah masyarakat yang berdomisili di lingkungan pantai dekat sekolah telah tumbuh kembang pedagang ikan kalangan menengah ke bawah, bahkan sebagian besar penduduk pantai tersebut bermata pencarian sebagai nelayan. Walaupun kehidupan nelayan pada umumnya terkesan sebagai kelompok masyarakat yang kurang beruntung dari aspek ekonomi, namun mereka merasa senang dan bahagia manakala kebutuhan sandang dan pangan dapat terpenuhi. Masyarakat tetap bertahan hidup dari pencarian sebagai nelayan (menangkap dan menjual) ikan tangkapannya dan/atau sebagai wirausaha atau pebisnis ikan mulai dari usaha kecil, usaha menengah, sampai sebagai pengelola industri perikanan. Kesejahteraan masyarakat sekitar sekolah belum ditopang oleh keberadaan program PBKL Perikanan di SMAN 2 Pekalongan, tetapi lebih banyak dipengaruhi oleh kehidupan masyarakat pesisir yang bermata pencaharian sebagai nelayan, pedagang ikan, karyawan pelabuhan, pengelola ikan, pembudidaya ikan, serta penangkap ikan tangkap.

Secara geografis, Kota Pekalongan berada di kawasan daerah pesisir pantai utara sehingga membuat Kota Pekalongan memiliki sumber daya perikanan dan kelautan yang melimpah. Keberadaan Pelabuhan Perikanan Nusantara yang berlokasi di Kelurahan Panjang Wetan, budidaya ikan tambak yang berpusat di tiga kecamatan yaitu Kecamatan Tirto, Wonokerto, dan Siwalan, serta budidaya ikan kolam yang tersebar di seluruh kecamatan yang ada di Pekalongan menunjukkan bahwa setiap tahun Kota Pekalongan berhasil memproduksi ratusan ribu ton ikan, dan dipasarkan dalam keadaan segar maupun diolah menjadi berbagai macam produk olahan ikan yang bernilai tinggi (Pemerintah Kota Pekalongan, 2011. Produk tersebut antara lain olahan teri, ikan asin, ikan pindang, ikan panggang, terasi dan bandeng presto. Di samping itu, produk perikanan daerah Panjang Wetan Pekalongan juga mengolah produk rumput laut yang cukup melimpah. Setiap tahun petani rumput laut dapat mengolah ratusan hingga ribuan ton, dan dipasarkan ke pasar lokal maupun pasar internasional (Triarso, 2012).

Hasil wawancara dengan pedagang ikan yang mengikuti lelang ikan menunjukkan bahwa permintaan ikan jauh lebih besar dibanding suplai ikan yang mendarat di pusat pelelangan ikan (PPI) Kota Pekalongan. Disamping itu, industri berbahan baku ikan di Kota Pekalongan telah banyak berkembang seperti terlihat pada Tabel 3.

Dari Tabel 3, terlihat bahwa kebutuhan ikan untuk pemenuhan kebutuhan industri berbahan baku ikan di Kota Pekalongan telah diproduksi sekitar 44.421 ton. Ekspor ikan merupakan sektor terpenting kedua setelah batik dan pakaian jadi. Ekspor di Kota Pekalongan meliputi ikan kakap, tuna dan jenis ikan lain yang dapat menghasilkan nilai di atas satu juta US\$. Kondisi ekspor ikan akan sangat tergantung dari hasil tangkapan dari kapal yang berlabuh di PPI Kota Pekalongan. Pengembangan perikanan tangkap juga didukung oleh pertumbuhan konsumsi ikan nasional maupun global. Konsumsi ikan nasional meningkat sekitar $4 \%$ per tahun dan konsumsi dunia meningkat sekitar 3\%. Konsumsi ikan yang terus meningkat baik di tingkat nasional maupun global merupakan pasar yang cukup prospektif bagi pengembangan usaha perikanan tangkap. Hal ini juga sesuai dengan kebijakan pemerintah 
Tabel 3 Perkembangan Industri Kota Pekalongan

\begin{tabular}{llcccl}
\hline No & Jenis Usaha & $\begin{array}{c}\text { Jml Unit } \\
\text { Usaha }\end{array}$ & $\begin{array}{c}\text { Jml tenaga } \\
\text { kerja }\end{array}$ & Produksi ikan & Jenis produksi \\
\hline 1 & Pengasinan & 33 & 721 & 27.720 ton & Ikan asin \\
2 & Pemindangan & 16 & 165 & 8.880 ton & Ikan pindang \\
3 & Pengasapan & 15 & 50 & 7.992 ton & Ikan asap \\
4 & Pembekuan & 10 & 53 & 7740 ton & ikan segar \\
\hline
\end{tabular}

Sumber: Pemerintah Kota Pekalongan, 2011

untuk terus meningkatkan pemberdayaan sektor kelautan terutama Sumber Daya Perikanan (Triarso, 2012)

\section{SIMPULAN DAN SARAN Simpulan}

Mengacu pada hasil dan pembahasan, dapat disimpulkan sebagai berikut. Pertama, SMAN 2 Pekalongan masih melanjutkan melaksanakan program PBKL Kelautan pada konsentrasi "perikanan" walaupun pihak Direktorat Pembinaan SMA Ditjen Pendidikan Menengah sudah tidak memberikan bantuan "dana operasional" untuk mendukung pelaksanaan dan optimalisasi program PBKL Perikanan. Bantuan dana operasional yang masih diperoleh berasal dari pemda kota Pekalongan sebesar Rp 20.000.000/ tahun. Dana tersebut dipergunakan untuk pembelian benih ikan, pakan ikan, biaya praktik, dan perawatan alat bantu lainnya. Terbatasnya dana operasional yang tidak mencukupi berdampak langsung pada kurang optimalnya pencapaian kompetensi peserta didik. Fungsi kolam ikan hanya sekadar sebagai laboratorium terbatas yang dikaitkan dengan mata pelajaran Biologi yang relevan dengan perikanan, seperti anatomi ikan dan budidaya ikan (pembenuran dan pembesaran ikan). Biaya perawatan (maintenance) sarana dan prasarana kolam ikan memerlukan biaya yang cukup tinggi seperti untuk pembelian pakan ikan dan perawatan jaring keramba. Kebijakan keberlanjutan program PBKL Perikanan ditetapkan berdasarkan musyawarah dan mufakat antara warga sekolah dengan komite sekolah (SMAN 2 Kota
Pekalongan) dengan mengacu pada prinsipprinsip manajemen berbasis sekolah (MBS).

Kedua, pemberian PBKL Perikanan bermanfaat bagi peserta didik SMAN 2 Pekalongan antara lain: a) peserta didik mengetahui keunggulan lokal di daerahnya, khususnya perikanan air tawar; b) peserta didik memahami dasar-dasar berbagai aspek pengetahuan yang berhubungan dengan keunggulan lokal di daerahnya (budi daya ikan); dan c) peserta didik memiliki dasar-dasar pengolahan sumber daya yang berkontribusi dalam pelayanan/jasa atau kegiatan lain yang berkaitan dengan keunggulan lokal (pembuatan makanan terbuat dari bahan dasar ikan, seperti sosis dan bakso); dan d) diharapkan peserta didik dapat menghidupi dirinya manakala terjun ke masyarakat di bidang perikanan tambak. Keunggulan program PBKL antara lain sebagai wujud pendekatan relevansi pendidikan dengan dunia kerja, di mana program PBKL dapat dijadikan sebagai media pendekatan dunia pendidikan dengan dunia kerja, khususnya bagi mayoritas siswa yang tidak melanjutkan pendidikannya ke jenjang yang lebih tinggi.

Ketiga, keberadaan keunggulan lokal perikanan di SMAN 2 Pekalongan belum memberikan nilai tambah (ekonomi) bagi kesejahteraan masyarakat yang bermukim di sekitar sekolah. Sementara itu, kesejahteraan masyarakat khususnya di sekitar sekolah telah ditopang oleh adanya pembudidayaan ikan (tawar) dan penangkapan ikan laut (nelayan) serta usaha pengelolaan perikanan sebagai mata pencaharian pokok masyarakat setempat. 


\section{Saran}

Mengacu pada simpulan, saran yang dirumuskan sebagai berikut. Pertama, dalam penanggulangan banjir air rob, sekolah menyusun perencanaan kebutuhan biaya renovasi kolam ikan untuk dimusyawarahkan bersama dengan seluruh warga sekolah dan para pemangku kepentingan pendidikan (stakeholders) termasuk instansi terkait yang menangani masalah banjir. Mengajukan proposal ke perusahaan yang ada di Kota Pekalongan untuk mendapatkan bantuan dana CSR (Corporate Social Responsilility).

Kedua, untuk meningkatkan wawasan perikanan dan kompetensi peserta didik, perlu melakukan kunjungan ke instansi terkait seperti Dinas Perikanan dan DUDI Perikanan setempat. Sekolah melakukan kerja sama dengan Dinas Perikanan setempat untuk memberikan penyuluhan terkait dengan PBKL Perikanan, misalnya: bimbingan teknis budi daya ikan, cara membuat dan merawat keramba apung, menstabilkan kandungan garam dalam air kolam (salinitas) air tambak, dan menjaga kadar besi (Fe) sesuai dengan ketentuannya. Di samping itu, perlu mengajak siswa melakukan wisata bahari ke tempat/perusahaan yang relevan, sehingga peserta didik dapat menambah pengetahuan dan wawasan pengelolaan perikanan (budi daya ikan) yang menjadi salah satu keunggulan lokal kota Pekalongan. Peserta didik diberi tugas melakukan praktik industri (perikanan) di sela-sela waktu liburan pada semester empat dan/atau semester lima. Begitu pula guru, perlu melakukan program "magang" di perusahaan perikanan atau tempat-tempat/ industri pengelolaan ikan.
Ketiga, sekolah bersama masyarakat setempat dan ibu-ibu PKK mengadakan kegiatan bersama pada waktu-waktu tertentu. Penyuluhan pengolahan makanan yang terbuat dari bahan pokok ikan (makanan rakyat) yang biasa dikonsumsi oleh masyarakat setempat bisa dilakukan dalam memperingati Hari Pendidikan Nasional, Hari Ulang Tahun Kota Pekalongan, Hari Kemerdekaan R.I. Melalui kegiatan tersebut masyarakat yang memiliki potensi wirausaha dapat membuat, memasarkan, dan mengembangkan pengetahuan dasar terkait dengan pengelolaan makanan tradisional boga ikan.

Untuk keberlanjutan dan kelancaran program PBKL, khususnya pendalaman materi pengelolaan ikan tambak, sekolah perlu melakukan kerja sama dengan pihak Dinas Perikanan Kota Pekalongan untuk mendapatkan bantuan penyuluhan perikanan sesuai dengan Undang-Undang Republik Indonesia Nomor 16 Tahun 2006. Para guru pengampu mata pelajaran Perikanan perlu melakukan studi banding ke SMKN 1 Bawang, Banjarnegara yang telah berhasil mengembangkan program perikanan sehingga memperoleh predikat "sekolah rujukan nasional" di bidang budi daya perikanan. Program perikanan tersebut meliputi: laboratorium budi daya perikanan, laboratorium pakan, laboratorium penyakit, dan belasan kolam untuk praktik siswa serta model kemitraan dengan instansi pemerintah (Dinas Pertanian, Perikanan, dan Peternakan) dan Universitas Gajah Mada (di bidang penelitian) serta dunia usaha/dunia industri (DUDI) di bidang perikanan. 


\section{PUSTAKA ACUAN}

Ahsin. 2012. Studi Evaluasi Kesiapan Pendidikan Berbasisi Keunggulan Lokal di SMA Negeri 1 Praya, Lombok Timur, Tesis, Universitas Pendidikan Singaraja dalam http:// pasca.undiksha.ac.id> homevol 2, No 1 (2012), diakses 17 Juli 2015.

Aman dan Kumulasa D. 2008. Faktor-faktor Pendukung Kualitas Pembelajaran Sejarah di SMA 5 Yogyakarta, Yogyakarta: UNY.

BPMP2T Kota Pekalongan. 2014. Potensi Perikanan, http://pekalongankota.go.id/index.php/id/ beranda/24-kota-pekalongan/profil-investasi/profil-investasi-sektor-perikanan-dan kelautan/55-potensi-perikanan, diakses tanggal 25 Juli 2015

Departemen Pendidikan Nasional. 2005. Peraturan Pemerintah Republik Indonesia Nomor 19 Tahun 2005 tentang Standar Nasional Pendidikan, yang telah diubah menjadi Peraturan Pemerintah Republik Indonesia Nomor 32/2013, Jakarta: Depdiknas

Direktorat Pembinaan Sekolah Menengah Atas. 2010. Konsep Pendidikan Berbasis Keuggulan Lokal (PBKL) di SMA: Jakarta: Direktorat Jenderal Mandikdasmen.

Dwitagama, D. 2007. Pendidikan Berbasis Keunggulan Lokal dalam https//akhmadsudrajat. wordpress.com/../konsep dasar, diunduh tanggal 15 Mei 2015

Herial. 2009. Studi Peningkatan Kebutuhan Pendidikan Kejuruan Untuk Mendukung Potensi Lokal Perikanan di Kecamatan Pangkalbalam dan Bukit Intan, Pangkal Pinang, Tesis, Program Pasca Sarjana Magister Teknik Pembangunan Wilayah dan Kota, Universitas Diponegogro, Semarang.

Iqbalon, A. 2015. Mendikbud-Menko Maritim Sepakat Optimalisasi SMK Maritim dalam www.antaranews.com/.../mendikbud-menko.m...diakses 27 Juli 2015.

Kusumaningsih, D. (tanpa tahun) Upaya Meningkatkan Kemampuan Berpikir Kritis Siswa Kelas X-C SMA Negeri 11 Yogyakarta Melalui Pembelajaran Matematika Dengan Pendekatan Contextual Teaching Learning Pada Materi Perbandingan Trigonometri. Skripsi, Yogyakarta: Universitas Negeri Yogyakarta, dalam: core.ac.uk/download /pdf/ 1105973.pdf diunduh tanggal 25 Juli 2015

Keputusan Mahkamah Konstitusi (MK) Nomor 5/PUU-X/2012 tentang Keputusan Pengabulan Pemohon Uji Materi Undang-Undang Republik Indonesia Nomor 20 Tahun 2003 tentang Sistem Nasional Pendidikan, Pasal 50 ayat (3).

Lena, D. 2006. Peranan SMK Kelautan dan Perikanan Dalam Meningkatkan Sumber Daya Manusia Kaitannya Dengan Ketahanan Keluarga, Tesis (tidak dipublikasikan), Program Pascasarjana Universitas Indonesia, dalam http://lib.ui.ac.id/ opac/ ui/detail. jsp? Id =97157danlokasi=lokal diakses 21 Juli 2015.

Mulyasa, E. 2005. Menjadi Guru Profesional, Menciptakan Pembelajaran Kreatif dan Menyenangkan, Bandung: Remaja Rosdakarya.

Pemerintah Kota Pekalongan. 2011. Sejarah Singkat Kota Pekalongan. http:// pekalongankota.go.id/index.php/id/beranda/24-kota-pekalongan/profil-investasi/profilinvestasi-sektor-perikanan-dan kelautan/55-potensi-perikanan, diakses 10 Juni 2015.

Purwanto, A.E., dan Sulistyastuti, R. D., 2012. Implementasi Kebijakan Publik: Konsep dan Aplikasinya di Indonesia, Yogyakarta: Penerbit Gava Media.

Priartini, 2014. Pengembangan Kurikulum Pendidikan Berbasis Keunggulan Lokal (PBKL) Tesis (tidak dipublikasikan) Universitas Pendidikan Indonesia (repository.upi.edu) 
perpustakaan.upi.edu.

Satria, 2005. Karkter Masyarakat Pesisir, dalam mfile.narotama.ac.id/../optimalisasi \%20pengelolaan\%20, diakses 9 Mei 2015.

SMAN 2 Kota Pekalongan. 2014. Profil Sekolah Menengah Atas Negeri 2 Pekalongan.

Suara Merdeka. 6 Maret 2015. Jurusan Perikanan SMK 1 Menjadi Rujukan, http:// berita.suaramerdeka.com/smcetak/jurusan-perikanan-smk-1-menjadi-rujukan/, diakses 3 Juli 2014.

Sudrajat, A. 2005. dalam https://pendidikan berbasis keunggulan lokal.konsep dasar, diakses 5 Mei 2015.

Triarso, I. 2012. Potensi dan Peluang Pengembangan Usaha Perikanan Tangkap di Pantura Jawa Tengah. Saintek Perikanan, 18(1), online http://ejournal.undip.ac.id/index.php/saintek/ article/view/6771/5537, diakses 25 Juli 2015, diakses 8 Juli 2015.

Wasino. 2008. dalam www.slideshare.net/.../pendidikan berbasis keunggulan lokal, diakses 15 Mei 2015.

Undang-Undang Republik Indonesia Nomor 16 Tahun 2006 tentang Sistem Penyuluhan Pertanian, Perikanan, dan Kehutanan, dalam www.pekalongankab.go.id diakses 8 Juli 2015 